\title{
Physical and Physiological Effects of Pre- and Post-Harvest Treatments Using Calcium Chloride and Jojoba Oil on the Guava Fruits Storage El-Dengawy, El. F. A. ${ }^{1}$;. M. Niamatt-Allah ${ }^{2}$; A. L. I. Tanas $^{3}$ and A. M. A. Saima ${ }^{1}$ \\ ${ }^{1}$ Department of pomology, Faculty of Agriculture, Damietta University, Egypt. \\ ${ }^{2}$ Department of Plant Science, Faculty of Science, Damietta University, Egypt. \\ ${ }^{3}$ Department of Agric. Botany, Faculty of Agriculture, Damietta University, Egypt
}

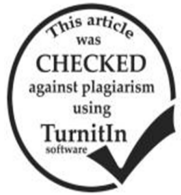

\section{ABSTRACT}

The objective of the present research is to find a treatment that preserves the quality of the guava fruits and prolong the marketing period under the room conditions. This study was conducted for two successive seasons 2014-2015 on 18 fruitful and almost identical guava trees at the age of seven years growing in sandy soil at a private commercial guava orchard located in Damietta Governorate - Egypt. The selected trees were subjected to three pre-harvest treatments ( 3 weeks before harvest time) which involved the foliar spray with tap water (control) or calcium chloride solution at concentration of either $2.5 \mathrm{~g} / 1$ or $5.0 \mathrm{~g} / \mathrm{l}$. After the fruits were harvested at the yellowish green color phase, the fruits of each of the three previous treatments were dipped in water only or $2 \%$ Jojoba oil for $5 \mathrm{~min}$ and stored under room conditions, at a temperature of $\left(27 \pm 1{ }^{\circ} \mathrm{C}\right)$ and a relative humidity of $70-80 \%$, for 12 days. The effects of the above-mentioned treatments on the physical and physiological characteristics of the fruit quality at the harvest time and at three intervals of 4 days during storage period were studied to get the best treatment for preserving fruits and quality during storage under room conditions. Various fruit quality attributes include the weight loss and decay $\%$ of fruits and vitamin C content, acidity $\%$, TSS, total soluble sugars content in fruit juice and also the change in the activity of the peroxidase enzyme in fruit flesh were measured. Most of the tested treatments reduced the weight loss and decay\% and the activity of peroxidase in fruit flesh as well as retained the fruits with a significantly higher quality comparing to the control during the storage period until the 12 th day. The most effective treatment involved the foliar spray of $\mathrm{CaCl}_{2}$ before the harvest by 3 weeks followed by dipping the fruits in $2 \%$ Jojoba oil after harvest. The fruits of such treatment were more pronounced in their contents of total sugars, vitamin $\mathrm{C}$ and TSS/acidity and it also resulted in a reduction in the decay $\%$ of fruits to $10.73 \%$ after a storage period of 12 days compared to range from 34.2 to $66.6 \%$ in other treatments and control.

\section{INTRODUCTION}

Guava (Pisidium guava) is a crop of tropical and subtropical climactic regions and it grows under a wide range of climatic and soil conditions and can tolerate alkaline soil up to $\mathrm{pH}$ 9.4. Now it is cultivated in several countries like India, China, Thailand, Pakistan, Mexico, Egypt, etc. (Morton, 1987).

Guava fruit has a high nutritive value and being one of the cheapest and richest sources of vitamin $\mathrm{C}$ as well as it contains small amounts of vitamin A, B, carbohydrates, oils and proteins (Menzel, 1985 and Dina et al., 2014). Guava, as in many other fruits, is rich in antioxidants that help to reduce the incidence of degenerative diseases such as arthritis, arteriosclerosis, cancer, heart disease, inflammation and brain dysfunction (Feskanich et al., 2000).

Guava fruit becomes fully ripe between three and five days at room temperature (Gongatti Neto et al., 1996). Guava is a fruit with high respiration rates and a very short postharvest life, which limits transportation and storage period. This is an aspect that hinders or even prohibits the shipment of these fruits to distant consumer markets (Xisto et al., 2004). Pre- or post-harvest applications of calcium salts extend the shelf life of many fruits through its effect on maintaining their cell wall structure and firmness, and reducing respiration rates, ethylene production, protein breakdown and decay (Poovaiah, et al., 1988; Cheour et al., 1990 and Singh et al., 1993). Mahajan and Sharma (2000) found that pre-harvest spray with $\mathrm{CaCl}_{2}$ at $1.0 \%$ was the most effective in enhancing the storage life of peaches. Moreover, Mootoo (1991) found that treatment of 4 to $6 \% \mathrm{CaCl}_{2}$ extended the shelf life of the treated fruits by 5 to 7 days on mango cultivar.

The application of wax coating helps to extend the shelf life of picked fruits by minimizing the weight loss due to natural migration process of moisture and gases. In this respect, jojoba oil is known as a liquid wax that can be used as coating materiel for fruits. Abd El Moneim and Abd El Mageed (2006) revealed that coating Washington navel orange fruits with jojoba oil led to reduce fruit decay and weight loss. The same results were obtained by Abd Alla et al., (2012) who found that, coating Costata persimmon fruits with jojoba oil helped to delay ripening and reduced weight loss and decay percentage.

The aim of the current study was to evaluate the effect of pre-harvest sprayed trees with calcium chloride solutions and post-harvest dipping the harvested fruits in jojoba oil solution at $2.0 \%$ for $5 \mathrm{~min}$ alone or in combinations on behavior of certain important fruits characteristics either at harvest date or during storage at ambient conditions.

\section{MATERIALS AND METHODS}

This study was conducted during 2014and 2015 seasons on 7 years old guava (Psidium guajava L.) trees, planted at $5 \times 4$ meters apart in a private orchard at Damietta governorate, Egypt. Trees grown in sandy soil under drip irrigation system received common horticultural practices that recommended by Agriculture Ministry.

\section{The investigated treatments}

Eighteen trees mostly uniform in growth, vigour and productivity were selected, divided in to 3 groups and each group was sprayed ( 3 weeks before harvest date) with one of the following solutions: Tap water (Control) and calcium chloride $\left(\mathrm{CaCl}_{2}\right)$ at either $2.5 \mathrm{~g} / 1$ or $5.0 \mathrm{~g} / \mathrm{l}$.

From each pre-harvest treatment, random samples of 120 green yellowish fruits were picked at commercial harvest time and divided into two groups. One group was dipped in tap water (control) for $5 \mathrm{~min}$ and the other group was dipped in solution of $2 \%$ jojoba oil for the same time. The studied treatments were as the following:

$\mathrm{T} 1=$ Spray preharvest with water and dipping postharvest into water (Control).

$\mathrm{T} 2=$ Spray preharvest with water and dipping postharvest into $2 \%$ Jojoba oil. 
$\mathrm{T} 3=$ Spray preharvest with $2.5 \mathrm{~g} / 1 \mathrm{CaCl} 2$ and dipping postharvest into water.

$\mathrm{T} 4=$ Spray preharvest with $2.5 \mathrm{~g} / 1 \mathrm{CaCl} 2$ and dipping postharvest into $2 \%$ Jojoba oil.

$\mathrm{T} 5=$ Spray preharvest with $5.0 \mathrm{~g} / \mathrm{C} \mathrm{CaCl} 2$ and dipping postharvest into water.

$\mathrm{T} 6=$ Spray preharvest with $5.0 \mathrm{~g} / 1 \mathrm{CaCl} 2$ and dipping postharvest into $2 \%$ Jojoba oil.

Storage procedure and fruit quality characteristics

Afterward, the treated fruits of Six treatments were packed in one layer into two carton boxes/replicate, twenty fruits per box, and stored up to 12 days at ambient conditions $\left(27 \pm 1^{\circ} \mathrm{C}\right.$ and $70-80 \%$ relative humidity "RH"). Fruit quality attributes (Total soluble solids (TSS), titratable acidity\% (Ac), ascorbic acid content (Vitamin C), TSS/Acid ratio, total soluble sugars percentage, and Peroxidase activity) were measured on the first box by taking 4 fruits on days $0,4,8$, and 12 . Weight loss $\%$ and decay $\%$ of stored fruits were also recorded on all fruits in the second box at the same intervals.

Fruit decay $\%$

Decay \% was calculated by visual observation of each sample as described by Zheng et al., (2007). A fruit with symptoms of disease, over softening and browning of skin at $25 \%$ or more was regarded as decayed and results were expressed as percentage of decayed fruits according to the following equation.

\section{Decay $\%=\frac{\text { Number of decayed fruits }}{\text { Initial number of stored fruits }} x \mathbf{1 0 0}$ Determination of Vit. C, acidity\% and TSS}

Ascorbic acid content (Vit. C) was determined in fruit juice according to Ranganna (1979) by the oxidation of ascorbic with 2, 6 dichlorophenol endophenol dye and the results were expressed as $\mathrm{mg} / 100 \mathrm{ml}$ juice. The titratable acidity $\%$ in fruit juice was measured by titrating with $0.01 \mathrm{~N} \mathrm{NaOH}$ in the presence of phenolphthalein as an indicator (Ranganna, 1979). The obtained results were expressed as an average citric acid \%. Total soluble solids (TSS) were measured in juice with a hand refractometer.

\section{Total sugars percentage}

The total sugars in fruit juice were determined using phenol sulphuric acid method as described by
Sadasivam and Manickam (1996). The obtained results were expressed as percentage.

\section{Peroxidase activity}

Peroxidase activity of guava fruits was determined as described by Abbasi et al., (1998) with slight modification. The reaction mixture was consisted of 1.7 $\mathrm{ml}, 15 \mathrm{mM} \mathrm{NaKPO}$ buffer ( $\mathrm{pH}$ 6.0), two substrates include $500 \mu \mathrm{l}$ of $0.1 \mathrm{mM}$ guaiacol and $500 \mu \mathrm{l}$ of $1.0 \mathrm{mM}$ $\mathrm{H}_{2} \mathrm{O}_{2}$, and $300 \mu \mathrm{l}$ enzyme extract in a $3 \mathrm{ml}$ cuvette. Peroxidase activities were noted for OD (optical density) change during 3 minutes at $470 \mathrm{~nm}$ and the results were expressed as unit $\mathrm{g}^{-1}$ protein.

\section{Statistical analysis}

The obtained data of the 2 tested seasons were statistically analyzed as randomized complete block using SPSS software with one way analysis. The differences among treatment means were compared with Duncan multiple range tests at 5\% level according to Duncan (1955).

\section{RESULTS AND DISCUSSION}

\section{The Physico-physiological properties of fruits stored at} room conditions

\section{Weight loss percentage of fruits}

The results in Table (1) showed that most of the treatments caused to reduce the loss of weight in the fruits during storage at the room conditions compared to the treatment of control, especially in the second season.

The best treatment in reducing the loss of fruit weight was the interaction involving pre-harvest foliar application with $5 \mathrm{~g} / \mathrm{l}$ calcium chloride and post-harvest dipping the fruits in Jojoba oil solution at a concentration of $2 \%\left(\mathrm{~T}_{6}\right)$. This may be due to retention of the treated fruits, with jojoba and calcium chloride at different concentrations, with their water content and nonevaporation due to the waxing the skin of the fruit. Similar results of effectively reducing total loss (weight loss and decay) percentages during fruits shelf life by foliar $\mathrm{CaCl} 2$ application were reported by El-Dengawy (2004). This beneficial effect of calcium application might be ascribed to increasing fruit firmness which resulted in the decrease in both transpiration and respiration rate (Singh, 1988).

Table 1. Effect of some pre- and postharvest treatments on weight loss percentage of guava fruits stored at the room conditions during 2014 and 2015 seasons

\begin{tabular}{|c|c|c|c|c|c|c|c|c|c|c|}
\hline \multirow{2}{*}{\multicolumn{3}{|c|}{ Treatments }} & \multicolumn{8}{|c|}{ Fruit weight loss percentage } \\
\hline & & & \multicolumn{8}{|c|}{ Intervals in days } \\
\hline \multirow{2}{*}{$\begin{array}{l}\text { Pre- } \\
\text { harvest }\end{array}$} & \multirow{2}{*}{$\begin{array}{c}\text { Post- } \\
\text { harvest }\end{array}$} & \multirow{2}{*}{ Sym } & \multicolumn{2}{|c|}{0} & \multicolumn{2}{|c|}{4} & \multicolumn{2}{|c|}{8} & \multicolumn{2}{|c|}{12} \\
\hline & & & 2014 & 2015 & 2014 & 2015 & 2014 & 2015 & 2014 & 2015 \\
\hline Control & Water & $\mathrm{T}_{1}$ & 00 & 00 & $0.80 \mathrm{~b}$ & $3.35 \mathrm{a}$ & $2.79 b$ & $5.78 \mathrm{a}$ & $4.18 b$ & $10.11 \mathrm{a}$ \\
\hline Control & J.O & $\mathrm{T}_{2}$ & 00 & 00 & $1.21 \mathrm{ab}$ & $2.93 \mathrm{c}$ & $2.63 \mathrm{~b}$ & $3.66 \mathrm{~d}$ & $3.80 \mathrm{c}$ & $5.16 \mathrm{~d}$ \\
\hline $\mathrm{CaCl}_{2}$ at $2.5 / 1$ & Water & $\mathrm{T}_{3}$ & 00 & 00 & 1.19ab & $2.17 \mathrm{~d}$ & $2.63 b$ & $3.33 \mathrm{~d}$ & $4.14 \mathrm{~b}$ & $5.20 \mathrm{~d}$ \\
\hline $\mathrm{CaCl}_{2}$ at $2.5 / 1$ & J.O & $\mathrm{T}_{4}$ & 00 & 00 & $0.95 \mathrm{ab}$ & $1.81 \mathrm{e}$ & $2.32 \mathrm{c}$ & $4.06 \mathrm{c}$ & $4.30 \mathrm{~b}$ & $6.16 \mathrm{c}$ \\
\hline $\mathrm{CaCl}_{2}$ at $5 \mathrm{~g} / 1$ & Water & $\mathrm{T}_{5}$ & 00 & 00 & $1.46 \mathrm{a}$ & $3.15 b$ & $3.34 \mathrm{a}$ & $5.22 b$ & $5.25 \mathrm{a}$ & $7.30 \mathrm{~b}$ \\
\hline $\mathrm{CaCl}_{2}$ at $5 \mathrm{~g} / 1$ & J.O & $\mathrm{T}_{6}$ & 00 & 00 & $0.20 \mathrm{c}$ & $1.25 \mathrm{f}$ & $0.78 \mathrm{~d}$ & $1.79 \mathrm{e}$ & $2.14 d$ & $3.77 \mathrm{e}$ \\
\hline F- test & & & & & NS & $* *$ & $* *$ & $* *$ & $*$ & $* *$ \\
\hline
\end{tabular}

Pre-harvest $=$ Spray on trees 3 weeks before harvest time, Sym. = Symbol, Post-harvest= Dipping fruit for 5 min, J.O = Jojoba oil solution at $2 \%$.

\section{Decay percentage of fruits}

The decay is caused by physiological injuries of the fruits during storage or as a result of the progress of the fruits in maturity or due to pathogens such as bacteria, fungi or yeast. The present results of fruits decay $\%$ in Table (2) showed that increasing storage periods at room conditions increases the percentage of fruit decay. Moreover, such results indicated that the use of $2 \%$ jojoba oil alone $\left(\mathrm{T}_{2}\right)$ or in combination with calcium spraying on trees at a concentration of $2.5 \mathrm{~g} / 1\left(\mathrm{~T}_{4}\right)$ or $5.0 \mathrm{~g} / \mathrm{l}\left(\mathrm{T}_{6}\right)$ resulted in a significant decrease in the decay percentage of fruits compared to control. The fruit decay percentage 
decreased by increasing the concentration of calcium used. Such results are in compatible with data of El-Dengawy (2004) and Abd El-Motty and El-Faham (2013). This beneficial effect of calcium application might be a scribed to increasing fruit firmness, which may reduce decay caused by several postharvest pathogens (Conway et al., 1991). The decrease of decay $\%$ by $2 \%$ jojoba oil are in a good agreement with the results of Baj et al, (2003) on Gala apple coated with $10 \%$ zein. This decreasing in decay percentages of treated samples was probably due to the effects of these coating on delaying senescence that makes the fruits more vulnerable to pathogenic infection as a result of the loss of cellular or tissue integrity (Patricia et al., 2005). Moreover, application of jojoba oil may be induced an increase of phenolic compounds which play the important defence against microorganism's attack of fruits. Such suggestion is strengthened by El-Naggar (1983) and Hagenmaier (2000), who proved that the phenolic compounds production was stimulated in orange trees and fruits treated with jojoba and essential oil.

Table 2. Effect of some pre- and postharvest treatments on decay percentage of guava fruits stored at the room conditions during 2014 and 2015 seasons

\begin{tabular}{|c|c|c|c|c|c|c|c|c|c|c|}
\hline \multirow{2}{*}{\multicolumn{3}{|c|}{ Treatments }} & \multicolumn{8}{|c|}{ Fruit decay percentage } \\
\hline & & & & & & Inte & in da & & & \\
\hline \multirow{2}{*}{$\begin{array}{l}\text { Pre- } \\
\text { harvest }\end{array}$} & \multirow{2}{*}{$\begin{array}{c}\text { Pot- } \\
\text { harvest }\end{array}$} & \multirow{2}{*}{ Sym } & \multicolumn{2}{|c|}{$\mathbf{0}$} & \multicolumn{2}{|c|}{4} & \multicolumn{2}{|c|}{8} & \multicolumn{2}{|c|}{12} \\
\hline & & & 2014 & 2015 & 2014 & 2015 & 2014 & 2015 & 2014 & 2015 \\
\hline Control & Water & $\mathrm{T}_{1}$ & 00 & 00 & 00 & 00 & $16.7 \mathrm{c}$ & $33.4 \mathrm{~b}$ & $51.4 \mathrm{a}$ & $75.0 \mathrm{~b}$ \\
\hline Control & J.O & $\mathrm{T}_{2}$ & 00 & 00 & 00 & 00 & $25.0 \mathrm{~b}$ & $37.5 b$ & $51.4 \mathrm{a}$ & $70.8 b$ \\
\hline $\mathrm{CaCl}_{2}$ at $2.5 / 1$ & Water & $\mathrm{T}_{3}$ & 00 & 00 & 00 & 00 & $30.6 \mathrm{a}$ & $48.6 \mathrm{a}$ & $50.0 \mathrm{a}$ & $83.3 \mathrm{a}$ \\
\hline $\mathrm{CaCl}_{2}$ at $2.5 / 1$ & $\mathrm{~J} . \mathrm{O}$ & $\mathrm{T}_{4}$ & 00 & 00 & 00 & 00 & $13.9 \mathrm{~d}$ & $5.6 \mathrm{~d}$ & $30.6 \mathrm{c}$ & $27.8 \mathrm{~d}$ \\
\hline $\mathrm{CaCl}_{2}$ at $5 \mathrm{~g} / \mathrm{l}$ & Water & $\mathrm{T}_{5}$ & 00 & 00 & 00 & 00 & $5.6 \mathrm{e}$ & $11.1 \mathrm{c}$ & $37.2 b$ & $30.6 \mathrm{c}$ \\
\hline $\mathrm{CaCl}_{2}$ at $5 \mathrm{~g} / 1$ & J.O & $\mathrm{T}_{6}$ & 00 & 00 & 00 & 00 & $5.0 \mathrm{e}$ & $5.4 \mathrm{~d}$ & $8.16 \mathrm{~d}$ & $13.3 \mathrm{e}$ \\
\hline F- test & & & & & & & $*$ & $* *$ & $* *$ & $* *$ \\
\hline
\end{tabular}

Pre-harvest= Spray on trees 3 weeks before harvest time, Sym. = Symbol, Post-harvest= Dipping fruit for 5 min, J.O = Jojoba oil solution at $2 \%$.

The best treatment in this aspect was $\mathrm{CaCl}_{2}$ spray at $5 \mathrm{~g} / \mathrm{l}$ followed by dipping in jojoba oil at $2 \%\left(\mathrm{~T}_{6}\right)$. Reduce the percentage of decay in stored fruits to $10.73 \%$ (mean of two seasons) in $\mathrm{T}_{6}$ compared to the other treatments (34.2\% to $66.6 \%$ as mean of two seasons). This result could be due to the role of jojoba oil with calcium chloride in increasing the hardness of skin cells and thus delay the process of loss of fruit to its hardness. This is considered one of the reasons for success in prolonging the life of fruits after harvesting and during storage. Gupta et al. (1984) reported that calcium compounds significantly thickened the middle lamella (calcium pectate) of fruit cells and thereby maintained the cell wall, which inhibits the penetration and spread of pathogens in fruits ultimately reducing the spoilage percentage of fruits. Similar observations were made by Selvan and Bal (2005) in guava fruits and Singh et al., (2008) in ber fruits.

\section{Vitamin $C$ content of fruits}

Data of Vitamin C content in fruit juice (Table 3) showed that most of the tested treatments maintained the higher concentration of vitamin $\mathrm{C}$ in fruit juice than the control during storage periods at room conditions up to 12 days. The fruits treated with jojoba oil alone $\left(\mathrm{T}_{2}\right)$ or preceded by pre-harvest spray on trees with $5 \mathrm{~g} / 1 \mathrm{CaCl}_{2}$ $\left(\mathrm{T}_{6}\right)$ tabulated the best results in reducing the loss of vitamin $\mathrm{C}$ content in fruits juice stored at room conditions compared to other treatments and suggest a major role for $\mathrm{Ca}^{+2}$ in maintenance of fruit vitamin $\mathrm{C}$ content. Such result could be attributed to increase oxidizing enzymes like peroxidase, ascorbic acid oxidase, polyphenol oxidase, catalase which might be causing decrease in ascorbic acid content of fruits (Singh et al., 2005). Activities of oxidizing enzymes might be reduced in $5 \mathrm{~g} / \mathrm{CaCl}_{2}$ treated fruits resulting in higher ascorbic acid content during the storage of fruits. This finding is in agreement with those of Singh and Singh (1999) in guava fruits and Singh et al., (2008) in bear fruits.

Vitamin $\mathrm{C}$ content in fruit juice decreased by increasing storage period, but the highest level of vitamin $\mathrm{C}$ in the Eighth day was in fruits of treatment $\left(\mathrm{T}_{6}\right)$. These results are in line with those of El-Anany et al., (2009) on apple fruits and El-Dengawy (2004) and Singh (1988) on guava fruits they stated that ascorbic acid content decreased as storage progressed.

Table 3. Effect of some pre- and postharvest treatments on juice vitamin $\mathrm{C}$ content of guava fruits stored at the room conditions during 2014 and 2015 seasons

\begin{tabular}{|c|c|c|c|c|c|c|c|c|c|c|}
\hline \multirow{2}{*}{\multicolumn{3}{|c|}{ Treatment }} & \multicolumn{8}{|c|}{ Fruit juice vitamin $C$ contents $(\mathrm{mg} / 100 \mathrm{ml})$} \\
\hline & & & \multicolumn{8}{|c|}{ Intervals in days } \\
\hline \multirow{2}{*}{$\begin{array}{l}\text { Pre- } \\
\text { harvest }\end{array}$} & \multirow{2}{*}{$\begin{array}{c}\text { Pot- } \\
\text { harvest }\end{array}$} & \multirow{2}{*}{ Sym } & \multicolumn{2}{|c|}{$\mathbf{0}$} & \multicolumn{2}{|c|}{4} & \multicolumn{2}{|c|}{8} & \multicolumn{2}{|c|}{12} \\
\hline & & & 2014 & 2015 & 2014 & 2015 & 2014 & 2015 & 2014 & 2015 \\
\hline Control & Water & T1 & $195.7 d$ & $290.3 c$ & $186.8 \mathrm{~d}$ & $191.2 \mathrm{c}$ & $103.0 \mathrm{~d}$ & $106.2 d$ & $106.8 \mathrm{~b}$ & $101.8 \mathrm{~d}$ \\
\hline Control & J.O & $\mathrm{T} 2$ & $167.5 \mathrm{e}$ & $244.4 d$ & $180.8 \mathrm{~d}$ & $244.6 b$ & $176.4 \mathrm{a}$ & $155.3 \mathrm{bc}$ & $129.6 \mathrm{a}$ & $163.8 \mathrm{a}$ \\
\hline $\mathrm{CaCl}_{2}$ at $2.5 / 1$ & Water & $\mathrm{T} 3$ & $222.0 \mathrm{c}$ & $303.1 \mathrm{c}$ & $204.9 b$ & $265.6 \mathrm{a}$ & $155.7 \mathrm{~b}$ & $158.5 \mathrm{bc}$ & $111.0 \mathrm{~b}$ & $125.5 \mathrm{c}$ \\
\hline $\mathrm{CaCl}_{2}$ at $2.5 / 1$ & J.O & $\mathrm{T} 4$ & $285.3 \mathrm{a}$ & $343.3 b$ & $198.8 \mathrm{c}$ & $191.2 \mathrm{c}$ & $179.5 \mathrm{a}$ & $163.0 \mathrm{~b}$ & $76.7 \mathrm{c}$ & $107.9 d$ \\
\hline $\mathrm{CaCl}_{2}$ at $5 \mathrm{~g} / 1$ & Water & T5 & $239.6 b$ & $234.3 d$ & $204.9 b$ & $200.0 \mathrm{c}$ & $131.7 \mathrm{c}$ & $148.7 \mathrm{c}$ & $111.3 b$ & $140.1 b$ \\
\hline $\mathrm{CaCl}_{2}$ at $5 \mathrm{~g} / 1$ & J.O & T6 & $244.6 b$ & $374.6 \mathrm{a}$ & $217.0 \mathrm{a}$ & $199.8 \mathrm{c}$ & $173.8 \mathrm{a}$ & $196.4 \mathrm{a}$ & $134.0 \mathrm{a}$ & $159.8 \mathrm{a}$ \\
\hline F- test & & & ** & ** & $* *$ & ** & ** & ** & ** & ** \\
\hline
\end{tabular}

Pre-harvest= Spray on trees 3 weeks before harvest time, Sym. = Symbol, Post-harvest= Dipping fruit for 5 min, J.O = Jojoba oil solution at $2 \%$.

\section{4- Acidity percentage in fruit juice}

Data of acidity $\%$ in fruits stored at the room conditions (Table 4) revealed that the studied treatments except for the $T_{4}, T_{5}$ and $T_{6}$ treatments caused increasing the acidity of fruit juice during 4 days storage on the atmosphere of the room. 
Spraying fruits on trees with $\mathrm{CaCl}_{2}$ at $5 \mathrm{~g} / \mathrm{l}\left(\mathrm{T}_{5}\right)$ resulted in a significant increase in fruit juice acidity at harvest time compared with control and other treatments.

At 12 days of storage, the lowest acidity level was observed in fruits treated on trees with calcium spray at concentration of $5 \mathrm{~g} / \mathrm{l}$ only $\left(\mathrm{T}_{5}\right)$. The post-harvest dipping of $2 \%$ of jojoba oil preceded with pre-harvest spry of $\mathrm{CaCl}_{2}$ at $2.5 \mathrm{~g} / \mathrm{l}\left(\mathrm{T}_{4}\right)$ came in second place at this point.

The highest acidity in fruits at 12 days storage was recorded in the control treatment. This means more decomposition of organic contents in the untreated stored fruits. In addition, fruit acidity decreased in the most calcium treated fruits during 8-12 days storage. This result might be due to the utilization of acids via respiration (Ulrich, 1970)

\section{Total soluble solid (TSS) content of fruits}

The present results of fruits $\mathrm{TSS} \%$ in Table (5) showed that in general, the percentage of total soluble solids decreases by increasing the storage period on the room atmosphere until the eighth day.

The highest values of $\mathrm{TSS} \%$ at the 4th day of the room conditions storage were in the control compared with other tested treatments. This means that the rate of polysaccharides hydrolysis and consequently the collapse and decay of fruits was faster in untreated fruits (control) than the other treatments.

Table 4. Effect of some pre- and postharvest treatments on juice acidity percentage of guava fruit stored at the room conditions during 2014 and 2015 seasons

\begin{tabular}{|c|c|c|c|c|c|c|c|c|c|c|}
\hline \multirow{2}{*}{\multicolumn{3}{|c|}{ Treatments }} & \multicolumn{8}{|c|}{ Fruit juice acidity \% } \\
\hline & & & & & & Interv & in days & & & \\
\hline \multirow{2}{*}{$\begin{array}{l}\text { Pre- } \\
\text { harvest }\end{array}$} & \multirow{2}{*}{$\begin{array}{c}\text { Post- } \\
\text { harvest }\end{array}$} & \multirow{2}{*}{ Sym } & \multicolumn{2}{|c|}{$\mathbf{0}$} & \multicolumn{2}{|c|}{4} & \multicolumn{2}{|c|}{8} & \multicolumn{2}{|c|}{12} \\
\hline & & & 2014 & 2015 & 2014 & 2015 & 2014 & 2015 & 2014 & 2015 \\
\hline Control & Water & $\mathrm{T}_{1}$ & $0.62 \mathrm{~b}$ & $0.53 b$ & $0.71 \mathrm{a}$ & $0.62 \mathrm{c}$ & $0.55 \mathrm{ab}$ & $0.51 \mathrm{a}$ & $0.66 \mathrm{a}$ & $0.66 \mathrm{a}$ \\
\hline Control & J.O & $\mathrm{T}_{2}$ & $0.59 \mathrm{bc}$ & $0.54 \mathrm{~b}$ & $0.71 \mathrm{a}$ & $0.73 a$ & $0.57 \mathrm{a}$ & $0.47 b$ & $0.57 \mathrm{~b}$ & $0.47 \mathrm{c}$ \\
\hline $\mathrm{CaCl}_{2}$ at $2.5 / 1$ & Water & $\mathrm{T}_{3}$ & $0.56 \mathrm{c}$ & $0.53 b$ & $0.67 b$ & $0.69 \mathrm{ab}$ & $0.52 \mathrm{bc}$ & $0.45 b c$ & $0.58 b$ & $0.47 \mathrm{c}$ \\
\hline $\mathrm{CaCl}_{2}$ at $2.5 / 1$ & J.O & $\mathrm{T}_{4}$ & $0.60 \mathrm{bc}$ & $0.52 b$ & $0.58 \mathrm{~cd}$ & $0.53 \mathrm{e}$ & $0.54 b$ & $0.47 \mathrm{~b}$ & $0.49 \mathrm{c}$ & $0.43 d$ \\
\hline $\mathrm{CaCl}_{2}$ at $5 \mathrm{~g} / 1$ & Water & $\mathrm{T}_{5}$ & $0.69 \mathrm{a}$ & $0.59 \mathrm{a}$ & $0.62 \mathrm{c}$ & $0.55 \mathrm{e}$ & $0.47 \mathrm{~d}$ & $0.43 \mathrm{c}$ & $0.48 \mathrm{c}$ & $0.42 d$ \\
\hline $\mathrm{CaCl}_{2}$ at $5 \mathrm{~g} / 1$ & J.O & $\mathrm{T}_{6}$ & $0.60 \mathrm{bc}$ & $0.58 \mathrm{a}$ & $0.59 \mathrm{c}$ & $0.57 \mathrm{~d}$ & $0.55 \mathrm{ab}$ & $0.53 \mathrm{a}$ & $0.57 \mathrm{~b}$ & $0.51 b$ \\
\hline F- test & & & ** & ** & ** & *** & ** & ** & NS & ** \\
\hline
\end{tabular}

Pre-harvest $=$ Spray on trees 3 weeks before harvest time, Sym. = Symbol, Post-harvest= Dipping fruit for 5 min, J.O = Jojoba oil solution at $2 \%$.

Table 5. Effect of some pre- and postharvest treatments on TSS percentage of guava fruits stored at the room conditions during 2014 and 2015 seasons

\begin{tabular}{|c|c|c|c|c|c|c|c|c|c|c|}
\hline \multirow{2}{*}{\multicolumn{3}{|c|}{ Treatments }} & \multicolumn{8}{|c|}{ Fruit TSS percentage } \\
\hline & & & \multicolumn{8}{|c|}{ Intervals in days } \\
\hline \multirow{2}{*}{$\begin{array}{l}\text { Pre- } \\
\text { harvest }\end{array}$} & \multirow{2}{*}{$\begin{array}{c}\text { Pot- } \\
\text { harvest }\end{array}$} & \multirow{2}{*}{ Sym } & \multicolumn{2}{|c|}{$\mathbf{0}$} & \multicolumn{2}{|c|}{4} & \multicolumn{2}{|c|}{8} & \multicolumn{2}{|c|}{12} \\
\hline & & & 2014 & 2015 & 2014 & 2015 & 2014 & 2015 & 2014 & 2015 \\
\hline Control & Water & $\mathrm{T}_{1}$ & $10.67 \mathrm{~b}$ & $11.33 \mathrm{a}$ & $8.25 a$ & $10.00 \mathrm{a}$ & $7.83 a$ & $7.33 a$ & $6.67 \mathrm{~b}$ & $7.00 \mathrm{c}$ \\
\hline Control & $\mathrm{J} . \mathrm{O}$ & $\mathrm{T}_{2}$ & $9.17 \mathrm{~d}$ & $9.00 \mathrm{~b}$ & $5.50 \mathrm{~d}$ & $6.50 \mathrm{~d}$ & $6.00 \mathrm{~b}$ & $7.33 \mathrm{a}$ & $9.00 \mathrm{a}$ & $10.00 \mathrm{a}$ \\
\hline $\mathrm{CaCl}_{2}$ at $2.5 / 1$ & Water & $\mathrm{T}_{3}$ & $11.17 \mathrm{a}$ & $8.97 b$ & $7.15 b$ & $8.83 b$ & $5.83 \mathrm{c}$ & $6.67 \mathrm{c}$ & $5.00 \mathrm{e}$ & $6.50 \mathrm{~d}$ \\
\hline $\mathrm{CaCl}_{2}$ at $2.5 / 1$ & J.O & $\mathrm{T}_{4}$ & $10.00 \mathrm{c}$ & $7.93 \mathrm{c}$ & $7.08 \mathrm{~b}$ & $7.83 c$ & $6.00 \mathrm{~b}$ & $7.17 \mathrm{~b}$ & $6.50 \mathrm{bc}$ & $7.50 \mathrm{c}$ \\
\hline $\mathrm{CaCl}_{2}$ at $5 \mathrm{~g} / 1$ & Water & $\mathrm{T}_{5}$ & $9.00 \mathrm{~d}$ & $9.00 \mathrm{~b}$ & $6.17 \mathrm{c}$ & $7.00 \mathrm{~d}$ & $7.50 \mathrm{a}$ & $6.00 \mathrm{~d}$ & $6.00 \mathrm{~d}$ & $6.33 \mathrm{~d}$ \\
\hline $\mathrm{CaCl}_{2}$ at $5 \mathrm{~g} / 1$ & J.O & $\mathrm{T}_{6}$ & $10.50 b$ & $8.94 b$ & $6.59 \mathrm{c}$ & $7.67 \mathrm{c}$ & $6.33 b$ & $7.33 \mathrm{a}$ & $6.33 c$ & $8.83 b$ \\
\hline F- test & & & $* *$ & $* *$ & NS & $* *$ & $* *$ & $* *$ & $* *$ & $* *$ \\
\hline
\end{tabular}

Pre-harvest $=$ Spray on trees 3 weeks before harvest time, Sym. = Symbol, Post-harvest= Dipping fruit for 5 min, J.O = Jojoba oil solution at $2 \%$.

At start of the storage period, the fruits treated by post-harvest dipping in $2 \%$ jojoba oil $\left(\mathrm{T}_{2}\right)$ or pre-harvest spraying with $5 \mathrm{~g} / 1 \mathrm{CaCl}_{2}$ alone $\left(\mathrm{T}_{5}\right)$ or in combination $\left(\mathrm{T}_{6}\right)$ gave the lowest values of $\mathrm{TSS} \%$ in fruits juice compared to other treatments. This was due to the role of $\mathrm{CaCl}_{2}$ in maintaining the lowest metabolic activity during storage of fruits.

Dipping the pre-harvest treated fruits with $5 \mathrm{~g} / \mathrm{l}$ $\mathrm{CaCl}_{2}$ in solution of $2 \%$ Jojoba oil (T6) led to a decrease in the percentage of TSS in fruits until the eighth day of storage on the atmosphere of the room and then increased until the 12th day under the same storage conditions. A similar trend was observed with the treated fruits after harvest only by dipping in solution of $2 \%$ jojoba oil $\left(\mathrm{T}_{2}\right)$. Such result is in line with those of Kittur et al., (2001) for banana and mango coated with polysaccharide-based coatings.

\section{TSS/acid ratio of fruits}

Spray-treated fruits with $\mathrm{CaCl}_{2}$ at $5 \mathrm{~g} / 1$ on trees $\left(\mathrm{T}_{5}\right)$ gave the lowest level of TSS / acid ratio (Av. = 13.78) at harvest compared to control $(\mathrm{Av} .=18.61)$ and other calcium treatment, $\mathrm{T}_{3},(\mathrm{Av} .=18.25)$.
After 4 days storage on the atmosphere of the room, most studied treatments reduced TSS / acid ratio (Av = 8.68 to 13.78$)$ compared to control (Av. $=16.28)$ specially treatment of dipping fruits in a $2 \%$ Jojoba oil solution alone before storage $(\mathrm{Av}=8.68)$.

After 8 days storage at the room condition, the combination treatments which include dipping the fruits before storage in a $2 \%$ solution of jojoba oil preceded by spraying with $\mathrm{CaCl}_{2}$ at $5 \mathrm{~g} / \mathrm{l}$ or $2.5 \mathrm{~g} / \mathrm{l}$ showed level of TSS / acid ratio (Av. = 12.5) significantly lower than control $(\mathrm{Av}=14.39)$.

After 12 days storage on the room condition, it was observed that the treatment of the fruits was immersed in $2 \%$ jojoba oil solution alone or preceded by spray on the trees with $\mathrm{CaCl}_{2}$ at $5 \mathrm{~g} / 1$ or $2.5 \mathrm{~g} / 1$ recorded TSS / acid ratio $(\mathrm{AV}=12.5)$ significantly less than control $(\mathrm{Av}=14.39)$, which is explained by increase TSS and reduce acidity.

7. Total sugars content of fruits

Concerning fruit soluble sugars content, the results in Table (7) showed increase sugars percentage in fruits stored at the room conditions until day 12 . The lowest level 
of sugars appeared in the fruits of control after the storage period of 8 or 12 days at the room atmosphere.

Treatment of fruits dipped in $2 \%$ Jojoba oil alone or pre-harvest sprayed with calcium chloride at a concentration of 2.5 or $5 \mathrm{~g} / 1$ resulted in significantly increase of the soluble sugars\% compared to control. Continuous increase in sugar content of fruit was found up to 12 days of storage. These results are in line with the findings of Gilfillan and Piner (1985), they found an increase in total sugar of film wrapped orange. Joseph and Aworh (1991) and Abd El-Moniem et al., (2006) concluded that fruit will reach high levels of soluble solids, ascorbic acid, sugar, and their lowest level of acidity as they ripened. The present results provided supporting evidence that coating guava fruits with jojoba oils helped to delay ripening and preserve fruit quality.

Table 6. Effect of some pre- and postharvest treatments on TSS/acid ratio of guava fruits stored at the room conditions during 2014 and 2015 seasons

\begin{tabular}{|c|c|c|c|c|c|c|c|c|c|c|}
\hline \multirow{2}{*}{\multicolumn{3}{|c|}{ Treatments }} & \multicolumn{8}{|c|}{ TSS/acid ratio of guava fruit juice } \\
\hline & & & \multicolumn{8}{|c|}{ Intervals in days } \\
\hline \multirow{2}{*}{$\begin{array}{l}\text { Pre- } \\
\text { harvest }\end{array}$} & \multirow{2}{*}{$\begin{array}{c}\text { Pot- } \\
\text { harvest }\end{array}$} & \multirow[b]{2}{*}{ Sym } & \multicolumn{2}{|c|}{$\mathbf{0}$} & \multicolumn{2}{|c|}{4} & \multicolumn{2}{|c|}{8} & \multicolumn{2}{|c|}{12} \\
\hline & & & 2014 & 2015 & 2014 & 2015 & 2014 & 2015 & 2014 & 2015 \\
\hline Control & Water & $\mathrm{T}_{1}$ & $17.2 \mathrm{~b}$ & $20.0 \mathrm{a}$ & $11.6 \mathrm{a}$ & $16.1 \mathrm{a}$ & $14.4 \mathrm{a}$ & $14.4 \mathrm{~b}$ & $10.1 \mathrm{~d}$ & $10.6 \mathrm{e}$ \\
\hline Control & J.O & $\mathrm{T}_{2}$ & $15.7 \mathrm{c}$ & $16.7 \mathrm{c}$ & $8.5 \mathrm{~d}$ & $8.9 \mathrm{~d}$ & $10.5 \mathrm{de}$ & $15.6 \mathrm{a}$ & $16.0 \mathrm{a}$ & $18.3 \mathrm{a}$ \\
\hline $\mathrm{CaCl}_{2}$ at $2.5 / 1$ & Water & $\mathrm{T}_{4}$ & $18.8 \mathrm{a}$ & $18.9 \mathrm{a}$ & $10.7 \mathrm{c}$ & $12.8 \mathrm{c}$ & $11.0 \mathrm{~cd}$ & $14.2 \mathrm{~b}$ & $9.9 \mathrm{~d}$ & $13.8 \mathrm{~d}$ \\
\hline $\mathrm{CaCl}_{2}$ at $2.5 / 1$ & J.O & $\mathrm{T}_{5}$ & $15.8 \mathrm{c}$ & $17.3 \mathrm{bc}$ & $12.2 \mathrm{a}$ & $16.7 \mathrm{a}$ & $11.1 \mathrm{~cd}$ & $13.5 \mathrm{c}$ & $13.3 \mathrm{~b}$ & $18.3 \mathrm{a}$ \\
\hline $\mathrm{CaCl}_{2}$ at $5 \mathrm{~g} / 1$ & Water & $\mathrm{T}_{7}$ & $12.3 \mathrm{~d}$ & $15.3 \mathrm{~d}$ & $10.6 \mathrm{c}$ & $12.7 \mathrm{c}$ & $14.4 \mathrm{a}$ & $14.0 \mathrm{~b}$ & $12.5 \mathrm{c}$ & $15.1 \mathrm{c}$ \\
\hline $\mathrm{CaCl}_{2}$ at $5 \mathrm{~g} / 1$ & J.O & $\mathrm{T}_{8}$ & $16.2 \mathrm{c}$ & $15.4 \mathrm{~d}$ & $11.2 \mathrm{~b}$ & $13.5 \mathrm{bc}$ & $11.5 \mathrm{bc}$ & $13.8 \mathrm{c}$ & $13.3 \mathrm{~b}$ & $17.1 \mathrm{~b}$ \\
\hline F- test & & & $* *$ & ** & ** & & $* *$ & $* *$ & $* *$ & \\
\hline
\end{tabular}

Table 7. Effect of some pre- and postharvest treatments on total sugars content of guava fruits stored at the room conditions during 2014 and 2015 seasons

\begin{tabular}{|c|c|c|c|c|c|c|c|c|c|c|}
\hline \multirow{2}{*}{\multicolumn{3}{|c|}{ Treatments }} & \multicolumn{8}{|c|}{ Fruit total sugars\% } \\
\hline & & & & & & Intert & in day & & & \\
\hline \multirow{2}{*}{$\begin{array}{l}\text { Pre- } \\
\text { harvest }\end{array}$} & \multirow{2}{*}{$\begin{array}{c}\text { Post- } \\
\text { harvest }\end{array}$} & \multirow{2}{*}{ Sym } & \multicolumn{2}{|c|}{$\mathbf{0}$} & \multicolumn{2}{|c|}{4} & \multicolumn{2}{|c|}{8} & \multicolumn{2}{|c|}{12} \\
\hline & & & 2014 & 2015 & 2014 & 2015 & 2014 & 2015 & 2014 & 2015 \\
\hline Control & Water & $\mathrm{T}_{1}$ & $6.09 a$ & $5.24 a$ & $6.60 \mathrm{bc}$ & $6.32 \mathrm{~d}$ & $7.45 \mathrm{c}$ & $6.42 \mathrm{c}$ & $8.59 b$ & $7.24 d$ \\
\hline Control & J.O & $\mathrm{T}_{2}$ & $5.91 \mathrm{a}$ & $5.60 \mathrm{a}$ & $6.69 b c$ & $7.06 b c$ & $7.86 \mathrm{a}$ & $7.22 \mathrm{~b}$ & $8.76 \mathrm{ab}$ & $8.08 \mathrm{bc}$ \\
\hline $\mathrm{CaCl}_{2}$ at $2.5 / 1$ & Water & $\mathrm{T}_{3}$ & $6.19 \mathrm{a}$ & $5.46 \mathrm{a}$ & $6.59 \mathrm{c}$ & $6.99 \mathrm{c}$ & $7.50 \mathrm{c}$ & $6.39 \mathrm{c}$ & $8.61 b$ & $8.44 a b$ \\
\hline $\mathrm{CaCl}_{2}$ at $2.5 / 1$ & J.O & $\mathrm{T}_{4}$ & $5.43 b$ & $5.61 \mathrm{a}$ & $6.72 \mathrm{ab}$ & $7.41 \mathrm{ab}$ & $7.69 b$ & $7.41 \mathrm{ab}$ & $8.84 \mathrm{a}$ & $8.25 b$ \\
\hline $\mathrm{CaCl}_{2}$ at $5 \mathrm{~g} / 1$ & Water & $\mathrm{T}_{5}$ & $5.59 \mathrm{~b}$ & $5.47 \mathrm{a}$ & $6.23 \mathrm{~d}$ & $7.27 \mathrm{~b}$ & $7.89 \mathrm{a}$ & $7.44 \mathrm{ab}$ & $8.14 \mathrm{c}$ & $7.90 \mathrm{c}$ \\
\hline $\mathrm{CaCl}_{2}$ at $5 \mathrm{~g} / 1$ & $\mathrm{~J} . \mathrm{O}$ & $\mathrm{T}_{6}$ & $5.33 b$ & $5.65 a$ & $6.82 \mathrm{a}$ & $7.76 a$ & $7.90 \mathrm{a}$ & $7.72 \mathrm{a}$ & $8.94 a$ & $8.54 \mathrm{a}$ \\
\hline F- test & & & $* *$ & ** & ** & ** & ** & ** & ** & ** \\
\hline
\end{tabular}

Pre-harvest $=$ Spray on trees 3 weeks before harvest time, Sym. = Symbol, Post-harvest= Dipping fruit for 5 min, J.O = Jojoba oil solution at $2 \%$.

\section{Peroxidase enzyme activity in fruits}

Data of peroxidase enzyme activity in fruits stored at the room conditions (Table 8) showed an increase of peroxidase activity in fruits stored at the room conditions by increasing the storage period until the eighth day. In general, most of the treatments caused a significant decrease in the activity of the enzyme peroxidase compared to control after storage periods of 8 or 12 days on the atmosphere of the room, especially in the second season. The same trend was observed at harvest time. Activities of oxidizing enzymes like ascorbic acid oxidase, peroxidase, catalase and polyphenol oxidase might be reduced in $5 \mathrm{~g} / \mathrm{C} \mathrm{CaCl}_{2}$ treated fruits during the storage of fruits. This finding is in agreement with those of Singh et al., (2008) and Goutam et al., (2010) in bear and guava fruits, respectively.

Table 8. Effect of some pre- and postharvest treatments on peroxidase activity of guava fruits stored at the room conditions during 2014 and 2015 seasons

\begin{tabular}{|c|c|c|c|c|c|c|c|c|c|c|}
\hline \multirow{2}{*}{\multicolumn{3}{|c|}{ Treatments }} & \multicolumn{8}{|c|}{ Fruit peroxidase activity (unit $\mathrm{g}^{-1}$ protein) } \\
\hline & & & \multicolumn{8}{|c|}{ Intervals in days } \\
\hline \multirow{2}{*}{$\begin{array}{l}\text { Pre- } \\
\text { harvest }\end{array}$} & \multirow{2}{*}{$\begin{array}{c}\text { Pot- } \\
\text { harvest }\end{array}$} & \multirow{2}{*}{ Sym } & \multicolumn{2}{|c|}{$\mathbf{0}$} & \multicolumn{2}{|c|}{4} & \multicolumn{2}{|c|}{8} & \multicolumn{2}{|c|}{12} \\
\hline & & & 2014 & 2015 & 2014 & 2015 & 2014 & 2015 & 2014 & 2015 \\
\hline Control & Water & $\mathrm{T}_{1}$ & $.113 a$ & $.114 \mathrm{a}$ & $.189 \mathrm{c}$ & $.194 b c$ & $.194 a$ & $.195 \mathrm{a}$ & $.195 \mathrm{a}$ & $.196 a$ \\
\hline Control & J.O & $\mathrm{T}_{2}$ & $.106 b$ & $.108 b$ & $.195 b$ & $.196 \mathrm{ab}$ & $.193 a$ & $.192 \mathrm{a}$ & $.195 \mathrm{a}$ & $.195 \mathrm{a}$ \\
\hline $\mathrm{CaCl}_{2}$ at $2.5 / 1$ & Water & $\mathrm{T}_{3}$ & $.094 \mathrm{c}$ & $.096 \mathrm{c}$ & $.199 \mathrm{a}$ & $.196 \mathrm{ab}$ & $.182 \mathrm{c}$ & $.181 d$ & $.175 b$ & $.174 \mathrm{c}$ \\
\hline $\mathrm{CaCl}_{2}$ at $2.5 / 1$ & J.O & $\mathrm{T}_{4}$ & $.109 \mathrm{ab}$ & $.108 b$ & $.196 a b$ & $.199 a$ & $.189 b$ & $.190 b$ & $.196 a$ & $.197 \mathrm{a}$ \\
\hline $\mathrm{CaCl}_{2}$ at $5 \mathrm{~g} / 1$ & Water & $\mathrm{T}_{5}$ & $.107 b$ & $.106 \mathrm{~b}$ & $.194 b$ & $.197 \mathrm{ab}$ & $.184 \mathrm{c}$ & $.186 \mathrm{c}$ & $.176 \mathrm{~b}$ & $.175 \mathrm{c}$ \\
\hline $\mathrm{CaCl}_{2}$ at $5 \mathrm{~g} / 1$ & $\mathrm{~J} . \mathrm{O}$ & $\mathrm{T}_{6}$ & $.114 \mathrm{a}$ & $.115 \mathrm{a}$ & $.196 \mathrm{ab}$ & $.194 b c$ & $.193 \mathrm{a}$ & $.194 a$ & $.168 \mathrm{c}$ & $.185 b$ \\
\hline F- test & & & ** & $* *$ & $* *$ & $* *$ & ** & $* *$ & $* *$ & $* *$ \\
\hline
\end{tabular}

Pre-harvest $=$ Spray on trees 3 weeks before harvest time, Sym. = Symbol, Post-harvest= Dipping fruit for 5 min, J.O = Jojoba oil solution at $2 \%$.

\section{CONCLUSION}

Based on the results obtained from this study, it is recommended to spray fruit guava trees before the usual harvest time of 3 weeks with calcium chloride solution at a concentration of $5 \mathrm{~g} / 1$ followed by post-harvest fruit soaking in $2 \%$ jojoba oil for $5 \mathrm{~min}$. This is considered the best treatment in the ability to reduce the potential loss after harvest and during storage, as well as maintaining the quality of stored fruits, which increases the length of validity of fruits in the market and also create the 
opportunity for export to distant markets. This increases the net income of farmers and producers of guava.

\section{REFERENCES}

Abbasi, N. A.; Kushad, M.M. and Endress, A.G. (1998). Active Oxygen-scavenging enzymes activities in developing apple flowers and fruits. Scientia Horticulturae, 74: 183-194.

Abd Allah, A.S.E.; Abd El-Moneim, E.A.A.; Saleh, M.M.S. and Naggar, M.A.A. (2012). Effect of jojoba oil emulsion on prolonging storage periods of Costata persimmon fruits. Asian Journal of Agricultural Science 4(1): $80-87$.

Abd El Moneim, E.A.A. and Abd El-Mageed, M.A. (2006). Effect of some oil emulsions and wax treatment on prolonging storage period of Washington navel orange fruits and its volatile components. Journal of Applied Sciences Research 2(7): $405-417$.

Abd El Motty, E.Z. and El-Faham, S.Y. (2013). Effect of oil coating and different wrapping materials on prolonging storage periods of Florida prince peach fruits. Journal of Applied Sciences Research, 9(4): $2927-2937$.

Baj, J., V. Alleyne, R.D. Hagenmaier, J.P. Mattheis and E.A. Baldwin, 2003. Formulation of zein coatings for apples (Malusdomestica borkh). Postharvest Biol. Technol., 28: 259-268.

Bashir, H. A.; A. Abu-Bakr and Abu-Goukh. (2003). Compositional changes du Gupta OP, Singh BP, Singh SP, Chauhan KS (1984) Effect of calcium compounds as pre-harvest spray on the shelf-life of peach cv Sharbat'Punjab Hort J 24:105-110ring guava fruit ripening. Food Chem., 80:557-563.

Cavalini, F.C.; Jacomino, A.P.; Lochoski, M.A.; Kluge, R.A. and Ortega, E.M.M. (2006). Maturity indexes for 'Kumagai' and 'Paluma' guavas. Rev. Bras. Frutic, Jaboticabal - SP, 28(2):176 - 179.

Cheour, F.; Wilemot, C.J.; Arul, Y.; Desjardins, J.; Makhlouf, P.M. and Gosselin, A. (1990). Effects of foliar application of cacl2 on postharvest strawberry ripening. Am. Soc. Hort. Sci. 115: 789792.

Conway, W.S., Sams, C. E., Abbott, J.A. and Bruton, B.D.1991.Postharvest calcium treatment of apple fruit to provide broad-spectrum protection against postharvest pathogens. Plant Dis. 75: 620-622.

Dina, A. O. M.; Ahmed, A.R. and Babikir, E.B. (2014). Physicochemical and nutritional value of red and white guava cultivars grown in Sudan. Journal of Agri-Food and Applied Sciences, 2(2):27 - 30.

Dubois, M.; Gilles, A.; Hamiltom, J.K.; Rebers, P.A. and Smith, F. (1956). Colorimetric method for determination of sugars and related substances. Analytical Chemistry 28(3):350-356.

Duncan, D.B. (1955). Multiple ranges and multiple F. test. Biometries.11: $1-42$.

El-Anany, A.M., G.F.A. Hassan, and F.M. Rehab Ali, 2009. Effects of edible coating on the shelf-life andquality of Anna apple (Malus domestica Borkh) during cold storage. J. of food Technology, 7(1): 5-1.
El-Dengawy, E.F.A. (2004). Guava fruit drop, yield, quality and shelf life following calcium foliar application. Proceeding Book, Fac. Agric. Assiut Univ., Egypt. The $4^{\text {th }}$ Scientific Conference of Agricultural Sciences 7-9 Dec., p. 506-521.

El-Naggar, M.A., 1983. Pathological and physiological on some storage diseases of tomato fruits and its control M.Sc. Thesis, Faculty of Agriculture, AlAzhar University, pp: 47-77.

Feskanich, D., Ziegler, R. G., Michaud, D. S., Giovannucci, E. L., Speizer, F. E., Willett, W. C., et al. (2000). Prospective study of fruit and vegetable consumption and risk of lung cancer among men and women. Journal of the National Cancer Institute, 92, 1812-1823.

Gangatti Neto, A.; Garcia, A.E. and Ardito, E.F.G. (1996). Goiaba para exportacao: Procedimentos de colheitae Pos-colheita, Brasilia: Embrapa-SPI, 1996, 35P.

Gilfilian, I.M. and G. Piner, 1985. Preliminary trails on polyethylene films wrap for South African citrus export fruits. Citrus and subtropical fruit J. 56: 1429.

Goutam, M.; Dhaliwal, H. S. and Mahajan, B. V. C. (2010). Effect of pre-harvest calcium sprays on post-harvest life of winter guava (Psidium guajava L.). J. Food Sci. Technol. 47(5):501-506.

Gupta, O.P, Singh, B.P, Singh, S.P, Chauhan, K.S. (1984). Effect of calcium compounds as pre-harvest spray on the shelf-life of peach cv Sharbat.' Punjab Hort, J. 24:105-110.

Hagenmaier, R.D., 2000. Evaluation of a PolyethyleneCandelilla coating for Valencia organes. Posthravest

Joseph, K. and O. Aworh, 1991. Composition, sensory quality and respiration during ripening and storage o edible wild mango (Invingia Jabonesis). Int. J. Food Sci. Technol., 1(26): 337-342.

Kittur, F.S., N. Saroja, Habibunnisa and R.N. Tharanathan, 2001. Polysaccharide-based composite coating formulations for shelf-life extension of fresh banana and mango. Eur. Food Res. Technol., 213: 306-311.

Mahajan, B.U. and Sharma, R.C. (2000). Effect of preharvest application of growth regulators and calcium chloride on physico-chemical characteristics and storage life of Peach (Prunus Persica L. )Batsh CV. Shane-Punjal-Haryana. J. Hort. Sci, 29: 41-43.

Mandal Goutam, M.; Dhaliwal, H. S. and Mahajan, B. V. C. (2010). Effect of pre-harvest calcium sprays on post-harvest life of winter guava (Psidium guajava L.). J. Food Sci. Technol. 47(5):501-506.

Menzel, C.M. (1985). Guava: an exotic fruit with potential in Queensland. Queensl. Agric. J. 111: 93-98.

Mootoo, A. (1991). Effect of post-harvest Calcium chloride dips on ripening changes in "Julie" mangoes . Trop. Sci.31: 243-248

Morton, J. 1987. Guava. p. 356-363. In: Fruits of warm climates. Julia F. Morton, Miami, FL.

Patricia, S., T. Palmu and C.R.F. Grosso, 2005. Effect of edible wheat gluten-based films and coatings on refrigerated strawberry (Fragaria ananassa) quality. Postharvest Biol. Technol., 36: 199-208. 
Poovaiah, B. W.; Glenn, G. M. and Reddy, A. S. N. (1988). Calcium and fruit softening. Physiology and Biochemistry. Horticulture Reviews, 10: 107152.

Ranganna, S. (1979). Manual of analysis of fruit and vegetable products. 2nd Ed. Tata McGraw. Hill, publishing company Limited, New Delhi, pp. 634.

Reyes, M. U. and Paull, R. E. (1995). Effect of storage temperature and ethylene treatment on guava (Psidium guajava L.) fruit ripening. Post-harvest Biol. and Tech., 6: 357-365.

Sadasivam, S. and A. Manickam, 1996. Phenolics, in: Biochemical Methods. 2 Edition. New Age, International Publishers, New Delhi.

Samson, F.A. (1980). Tropical fruit. Tropical Agriculture Series, pp. 214. Longman ISBN, London, New York (c.f. M.Sc. Zaghloll Ali, 1994, Alex. Univ. Egypt)

Selvan MT, Bal JS (2005) Effect of different treatments on the shelflife of Sardar' guava during cold storage. J Res Punjab Agric Univ 42:28-33.

Selvan, M.T., Bal, J. S. (2005) Effect of different treatments on the shelf-life of 'Sardar' guava during cold storage. J. Res. Punjab Agric. Univ., 42:28-33.

Sengh, B. P.; Tandon, D. K. and Kabra, S. K. (1993). Changes in post-harvest quality of mangoes as affected by pre-harvest application of Calcium salts. Scienta Hort., 54: 211-219.
Singh, G. (1988). Effect of calcium nitrate and plant growth regulators on the storage of 'Allahabad Safeda' guava. Indian J Hort 45:45-50.

Singh, J.P., Singh, S.P. (1999) Effect of pre-harvest spray of calcium nitrate on shelf-life of guava (Psidium guajava L.) fruits cv. 'Allahabad Safeda'. J. Appl. Biol. 9:149-152.

Singh, S., Singh, A.K., Joshi, H.K. (2005). Prolong storability of Indian gooseberry (Emblica officinalis Gaertn.) under semiarid eco-system of Gujarat. Indian J. Agric. Sci. 75:647-650.

Singh, S., Singh, A.K., Joshi, H.K., Bagle, B.G., Dhandar, D.G. (2008). Storability of ber (Zizyphus mauritiana Lamk) fruit in semi arid environment. J. Food Sci. Technol. 45:65-69.

Ulrich, R., (1970). Organic acid. In: The Biochemistry of Fruits and their Products. Vol.1. (A.C. Hulme Ed.). Academic Press, London and New York, p. 89-115.

Xisto, A. L. R. P. et al. Textura de goiabas '2004 Pedro Sato' submetidas à aplicação de cloreto de cálcio. Ciência e Agrotecnologia, v. 28, n. 1, p. 113-118.

Zheng, Y., Wang, S.Y., Wang, C.Y., and Zheng, W. (2007). Changes in strawberry phenolics, anthocyanins and antioxidant capacity in response to high oxygen treatments. LWT- Food Science and Technology, 40(1): 49-57.

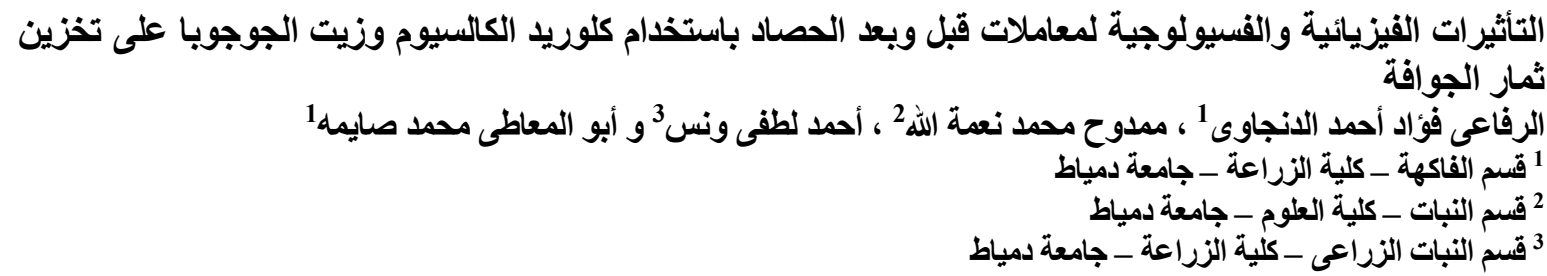

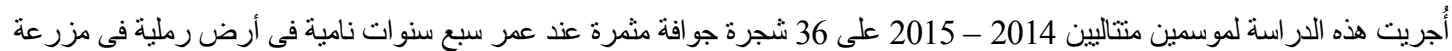

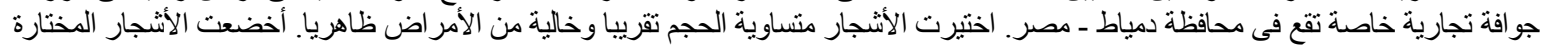

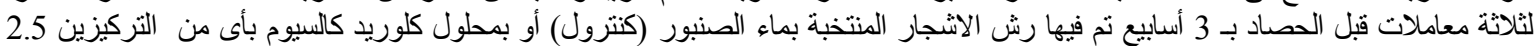

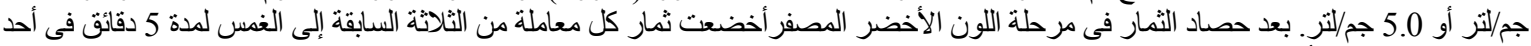

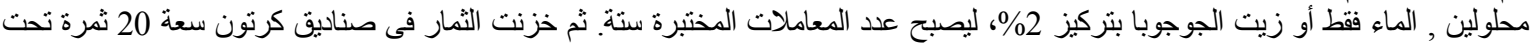

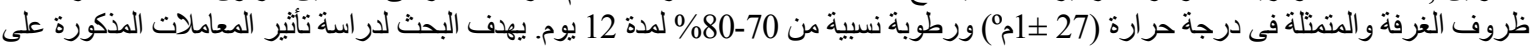

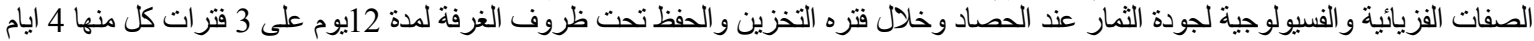

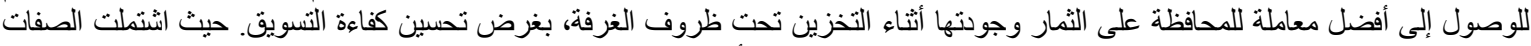

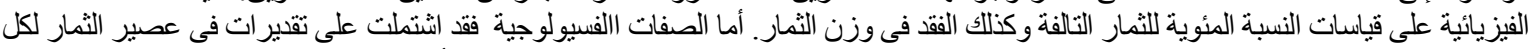

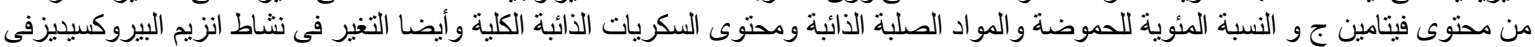

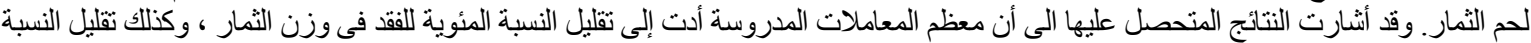

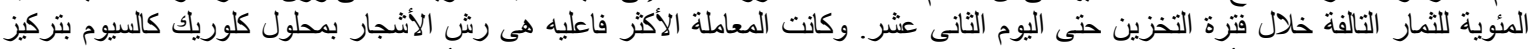

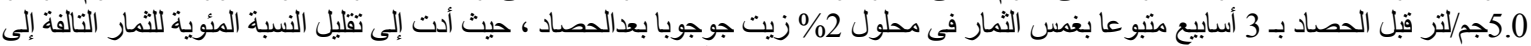

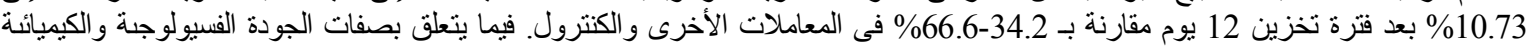

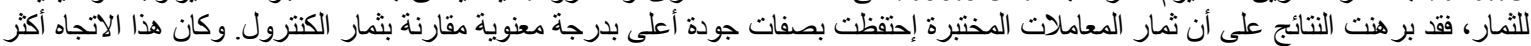

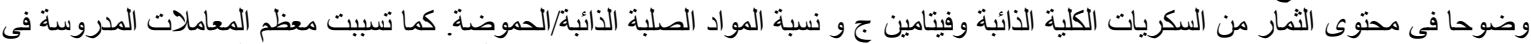

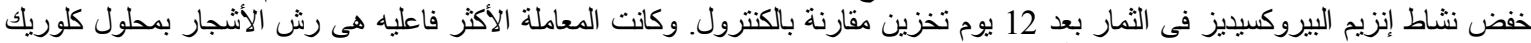

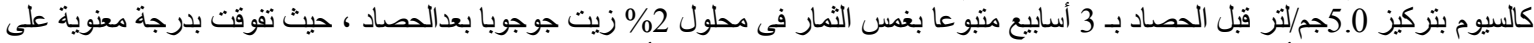

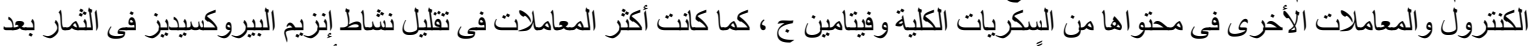

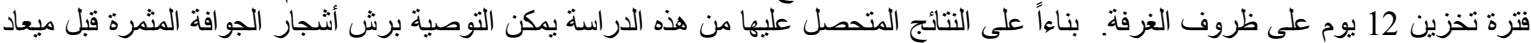

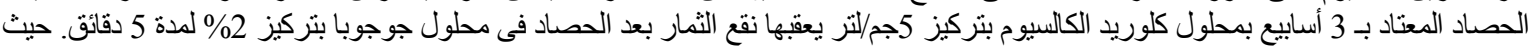

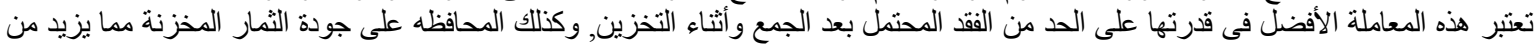

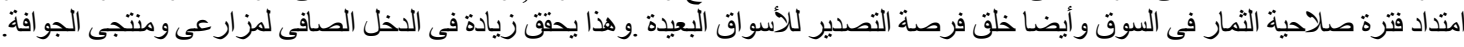

